\title{
AN ECONOMETRIC APPROACH TO FACTORS AFFECTING CROP INSURANCE IN ROMANIA
}

\section{Simona Laura Dragos, Codruta Mare}

\section{Issues Related to Agriculture Development}

The structure of the national economies throughout the world has undergone important changes in the 20th and 21st centuries. These changes have been carefully monitored and analyzed, especially in relation to the continuous population growth that needs more and more natural resources. While there is already no need to assess the weight of agriculture in the developed economies, recent studies have emphasized a decreasing trend of agriculture also for the developing and third world economies [21], [29]. For example, the first paper cited shows that the weight of the agricultural sector in the total economy based on the value added has more than halved in a period of 10 years, from 15.9 in 1998 , to 6.4 in 2007. The descending trend for Romania has continued later on. A more dramatic drop is to be found on the other side of the World, in countries like India [29], with a continuously increasing population that needs food.

There are a lot of factors affecting the evolution and development of the agricultural sector. Among them, the most important resides in the economic theories of efficiency and utility. Thus, every investor, regardless of the area of activity, takes decisions in order to maximize profit and utility. For the economic agents involved in agriculture, this process is harder than for those in other sectors, as risks are higher. Among the main causes to be found in the recent literature, we mention: lack of financial assistance [37], volatility of incomes in agriculture [29] due both to high price volatility and to natural disasters [28] that lead to a low level of welfare [2] and other types of causes related to the market, technical or political risks [28], [25], [35] and so on. The best way to overcome all these threats and improve rural welfare is through agricultural insurance.
An excellent review of the main problems, solutions and politics regarding crop insurance is made by Makki [19]. He approaches the possible causes of the nonexistence of marketbased private insurance in agriculture and of the original proposals to reform crop insurance. The proposed theoretical background prefigures the factors that have to be considered in order to explain the small farmer's decision to insure. The economic mechanism of the farmer's reactions to price insurance, gross revenue insurance, crop insurance, price plus crop insurance and portfolio insurance are examined by Turvey [33].

Boyd et al. [5] examine the main principles underlying crop insurance. They suggest some possible solutions to the challenges for crop insurance development in the emerging economies (especially China), based on the experience of some developed agricultures (USA and Canada). Enjolras et al. [13] undertake a representative survey of French farms regarding the identification of incentives for the crop insurance decision. They find that the decision to buy insurance is positively related to the past amount of claims. Insurance appears too expensive for smaller farms so they are subscribed mainly by larger farms, but capital structure or return on investment do not significantly determine the insurance decision. In our study we demonstrate that some factors like the proximity to a city, the size of a village, the level and the profile of the farmers' training can be significant in an emerging economy (Romania), even though they are not significant in a developed economy (France).

Some studies analyze particular features regarding specific calamities (see [23] for hail insurance). The effectiveness of some policies for insurance support is evaluated comparatively: on one hand there is an area insurance plan and on the other hand there is an Income 
Equalization Deposit (IED) scheme for small farmers. The academic literature is also concerned with analyzing the limited success of some innovative methods like Index-based Agricultural Insurance [4].

Agriculture in Romania has developed in the past 20 years starting from the publicly owned farms typical of the communist period. This type of farms had no need for risk management practices, as everything was supported by the state. The period of collective farms was obviously followed by the privatization process [36]. During this period, the land was divided among citizens, who started to operate in a subsistence agricultural sector. The expansion of the subsistence agricultural sector was also sustained by other post-communist evolutions. One, in particular, is very well emphasized by Mare [21] - due to lack of labour market flexibility and of labour market education, along with the evanescence of the great industrial state-owned companies, people went either in long term unemployment, or to work in agriculture. Consequently, more than $66 \%$ of the rural population has become engaged in agricultural activities [10]. The same study reveals that only around 150,000 of them are actually officially employed in agriculture. Preoccupations with the study of the agricultural environment in Romania and methods to improve it are not new. As Ştefănescu [31] points out, proposals of measures to improve the life of peasantry, in particular, and the agricultural sectors, in general, date back to the 19th century. They have evolved over time, according to the characteristics of the periods under discussion. Nowadays, the main subjects of interest relate to ecological issues [11] and means of sustaining the development of the agricultural sector. Our subject of study - issues related to the development of the agricultural sector insurance - belongs to the second group of research.

The studies of Gomez-Limon et al. [17], Hardaker et al [18] and Toledo, Engler [32] estimated the farmer's risk preferences. If the risk of loss is perceived as too great to assume, a possible farmer's decision is to use an agricultural insurance scheme to mitigate the impact of unpreventable risks [16].

The second part of the study presents some specific aspects related to crop insurance in Romania. Because of the specificity of each agricultural market, the policies for implementing the insurance crop systems have to be personalized for every economy. Romania has an emerging economy and agriculture, being an ex-communist society, still predominantly traditionalist. For the Central and Eastern European Countries, Njegomir and Stojic [24] believe that the solution for improving the competitiveness of local insurance markets and for providing more affordable insurance coverage is the inflow of foreign capital. The governmental decisions must be in accordance with the significant factors that influence the buying decision of an insurance policy. We assume that unlike countries with advanced agriculture sectors, where the decision to purchase insurance is positively related to the past amount of claims, in Romania (as well as in the other emerging agricultures) the decisive role is still played by several socio-cultural, economic or geographical factors like: the size of the village, the proximity to the city, the level and profile of education, the agricultural area owned by the farmer, the type of agricultural crop. As a consequence, the key objective of this study is to examine (using econometric tools) which of these factors are relevant and to recommend adequate policies for supporting the development of crop insurance.

As it will be seen, the majority of the results are the ones expected. For example, the level of education significantly determines the choice of buying an agricultural insurance. Moreover, the high level of traditionalism in countries like Romania also has an important impact upon the decision. Additionally, interesting results were obtained when studying the influence of the crop type.

\section{Crop Insurance in Romania}

Romania has a large area of arable land (around 8.2 million ha according to the agricultural census 2010-2011) and great potential concerning crop insurance. In the period $2005-2007$ only a percentage of $15-18 \%$ of the total arable surface was insured. In the crop year 2007-2008 the percentage rose to $43 \%$, which represents 3.5 million ha insured. This increase is explained through the Governmental subsidies granted on insurance subscription. In 2009 the insured arable surface dropped again to 2.8 million ha due to abrogation of subsidies [1]. Another characteristic of the Romanian 
crop insurance market is that over $90 \%$ of the the insured are large farm owners who have over 100 ha to administer. Among the causes which led to this situation are: land fragmentation, lack of financial resources, lack of information from insurance companies and lack of trust in the insurance sector.

The agricultural sector is characterized by high risk and uncertainty. In Romania, due to strong weather variations, production and yields fluctuate a lot. As a consequence, price volatility is also extremely high. Usually, in years with good yields and production, prices decrease, while in years with low levels of crops, prices increase [3]. There are two main types of crop insurance available to farmers, namely: the single risk insurance and the combined (multirisk) insurance. The first category covers only one peril and is appropriate for small farmers, while the second one combines more risks and is sold in packages.

In Romania the insurers do not insure the disaster risks, whose regulation was enforced in 2002, when Law no. 381/2002 regarding the granting of compensations for natural calamities was issued. Natural calamities represent the quantitative and qualitative crop losses because of damaging natural phenomena on large areas. The early warning system proposed by Furdu, Tomozei and Pandele [14] could represent a further step in the management of natural disasters. (By law, natural phenomena and diseases are considered to be the following: excessive drought, floods coming from overflowing rivers or broken bridges, heavy rains, excessively low temperatures below the biological resistance limit of the plant, heavy snow falls causing losses in the vegetal and livestock sectors, rapid melting of the snow causing floods, rivers overflowing, hurricanes.) In the case of loss caused by calamities stipulated in the mentioned law, the agricultural producer is indemnified by the state, but only if the producer has insured the "standard" risks (insurable risks).

Natural calamities which have stricken Romania in the recent years have determined the insurance companies to believe that the coverage degree concerning agricultural insurance will significantly increase [22]. But farmers do not perceive the risk, believing that disasters will not affect them. If they lose their crops, they expect to be indemnified by the government.
In order to improve the system and to stimulate farmers to insure against risks, the state attempted to encourage agricultural producers to insure by subsidizing the premium, and not by paying all the losses. In 2010, by the Governmental Decision no. 756/2010 regarding the state subsidy in agriculture for the insurance premiums, the subsidy was set at $50 \%$ or $70 \%$, in accordance with the insured risks. Nevertheless, only somewhere between $20-25 \%$ of the Romanian cultivated area is covered by insurance. Crop insurance has a higher penetration ratio within associations and among those farmers that exploit larger land areas. Considering the subsidies that the state provides for legal entities concerning the insurance premium, a possible solution for the farmers who practise a subsistence agriculture (on small areas of 1-2 ha) to benefit from these could be association.

Agricultural insurance had a development far stronger than the market average, rising by over $77 \%$ in the first half of 2011 , compared to the value of subscriptions in the same period of 2010. The nine insurance companies that reported subscriptions for agricultural insurances cumulated gross written premiums whose value reached 10 million euro (around $1 \%$ of the market), over 4 million euro more than the total at the end of June 2010. For the first nine months of the year 2012, on the Romanian agricultural insurance market the gross written premiums (GWP) subscribed reached 14 million Euro, a $33 \%$ increase since the same period of the year 2011 .

Among the determining factors that influence insurance coverage, [8] mention geographical localization of sowed fields, structure of the crops and technical costs required by each crop type in the process of production. The insurance is available for the current agricultural year, with the possibility of periodical updates. The sum insured for crops is the value declared by the insured and accepted by the insurer, depending on the production technical costs. The insurance premium depends on the crop's sensitivity to the insured risk factors, the frequency of the risk factors, the localization of the crop, the amount insured - which, according to the type of insurance policy, might cover the technological expenses or the value of production.

Based on the statistics for the last 50 years, the insurance premiums ratio for crops in the 
European community was established at $6-7 \%$ of the insured value. In Romania, the standard premium ratio (from the catalogue) is $3-3.5 \%$ of the insured value, lower than the European level. Because of the discriminating competition on the Romanian insurance market, the ratio quotation applied is around $1.7-1.8 \%$, being unsustainable if we refer to the acquisition and administration costs of the insurer. This leads to a situation where substantial losses are registered for the insurance companies which subscribe agricultural insurance contracts because of the loss ratio of above $70 \%$.

The lack of financial resources and the lack of information and education are some of the main reasons for which agricultural insurance is not fully employed as a risk management instrument in Romania. Studies have shown that, in order to have a rapid expansion of the agricultural insurance market, governmental intervention is needed [15], especially in the former communist countries [9] or in other emerging countries like Indonesia [27]. Clipici [7] considers that for the farmers in emerging countries the use of agricultural insurance represents the transition from subsistence farming to sustainable farming.

The paper analyzes, thus, the agricultural insurance market in Romania, bearing in mind all the above mentioned aspects. Overcoming losses due to natural disasters through insurance has an immediate stabilising effect on the rural households' incomes. Thus, agricultural insurance increases the welfare of the rural areas, leading to higher efficiency and utility.

\section{Data}

Data was collected in the period April - October 2011, in the North-West Region of Romania. The sample includes 18 villages from the six counties that make up the region (Satu Mare, Maramures, Salaj, Bihor, Cluj and Bistrita Nasaud). After eliminating farmers with missing answers for at least one variable, the final sample consists of 308 farmers. For them, answers were available for all variables taken into account in the regression. The definition of the variables and some descriptive statistics are presented in Tab. 1.

\section{Tab. 1: Explanations of the variables and some descriptive statistics (part 1)}

\begin{tabular}{l|l|c|c} 
& Explanations & $\begin{array}{c}\text { Mean or } \\
\text { proportion }\end{array}$ & St. dev. \\
\hline Endogenous variables & & & \\
\hline Insurance (multiple) & $0-$ if the farmer does not have an insurance & $78.9 \%$ & \\
& $1-$ if the farmer has partial (single risk) insurance & $12.0 \%$ & \\
& $2-$ if the farmer has a full-type (combined) insurance & $9.1 \%$ & \\
\hline Insurance (binary) & 0 - if the farmer does not have an insurance & $78.9 \%$ & \\
& $1-$ if the farmer has an insurance & $21.1 \%$ & \\
\hline Exogenous variables & & & \\
\hline Inhabitants & Numerical attribute. Number of inhabitants in each village. & 737 & 707 \\
\hline Distance city & Numerical attribute. Distance, in km, from the most significant city & 25.7 & 13.1 \\
& (over 10000 inhabitants) & & \\
\hline Age & Numerical attribute & 49.4 & 11.9 \\
\hline Education & $0-$ primary or secondary school & $36.7 \%$ & \\
& $1-$ high-school or professional school & $53.6 \%$ & \\
\hline Agricultural studies & $2-$ university degree & $9.7 \%$ & \\
& $0-$ if not & $86.7 \%$ & \\
\hline Economic studies & $1-$ if yes (including agricultural economics) & $13.3 \%$ & \\
\hline Area & $0-$ if not & $77.9 \%$ & \\
\hline & $1-$ if yes (including agricultural economics) & $22.1 \%$ & \\
\hline & The total area detained by the farmer (ha) & 4.89 & 1.79 \\
\hline
\end{tabular}


Tab. 1: Explanations of the variables and some descriptive statistics (part 2)

\begin{tabular}{l|l|c|c} 
& Explanations & $\begin{array}{c}\text { Mean or } \\
\text { proportion }\end{array}$ & St. dev. \\
\hline Vegetables & & $22.4 \%$ & \\
\hline Vine & Dummy variable. & $17.8 \%$ & \\
\cline { 1 - 3 } Field crops & Indicates the main type of agricultural crop (covering most of the & $40.0 \%$ & \\
\cline { 1 - 3 } Pomiculture & area or having the highest weight in the farmer's income) & $19.8 \%$ & \\
\cline { 3 - 4 } & &
\end{tabular}

Source: own

\section{Methodology and Results}

Starting from the idea that quantitative economic forecasting is more reliable than the qualitative type [20], we have based our research on the first type of methods. While reviewing the most recent literature, both in Economics and Agricultural studies, quantitative methods prevail [6], [26], [30], [34]. The first research cited in this paragraph uses the quantitative approach in order to construct a simulation model intended to evaluate new operating policies in a corn flour production plant. The last study combines quantitative methods and economic theory [34] in order to estimate economic efficiency. Constructing a simulation model based on production and reproduction in a dairy herd, the authors succeeded in quantifying the economic value of productive and functional traits. The other studies employ a more complex approach to the quantitative methods of analysis. We have observed that most of the researches conducted in this area use methods and techniques belonging to time series and qualitative variables econometrics, especially logistic models. Ramirez-Valverde et al. [26] make a theoretical incursion in the problems of non-stationarity and spurious regression in time series logistic models using binary variables. Ramirez-Valverde has previously studied logistic regression. Together with Sifuentes-Amaya [29], they have also analyzed the problems derived from specifying incorrect logistic models. Some recent empirical studies evaluate, through discrete regression tools, the behaviour of the farm market versus supermarkets [12] or factors which affect the crop insurances in emerging markets [33].

We employ two types of econometric models in order to explain two types of decisions: a) the choice of the insurance type; and $b$ ) the option of buying an insurance policy.

a) To model the choice of the insurance type, the Ordered Logit model was employed, which, in its general form, can be written as:

$$
\begin{gathered}
\text { Prob }\left(y_{i}=j \mid x, b, c\right)=F\left(c_{j+1}-x_{i} b\right)-F\left(c_{j}-x_{i} b\right) \\
\operatorname{Prob}\left(y_{i}=j \mid x, b, c\right)=\frac{\exp \left(c_{j+1}-x_{i} b\right)}{1+\exp \left(c_{j+1}-x_{i} b\right)}-\frac{\exp \left(c_{j}-x_{i} b\right)}{1+\exp \left(c_{j}-x_{i} b\right)}
\end{gathered}
$$

$i=\overline{1, N}$ index of each farmer,

$y_{i}=0$ if the farmer does not have an insurance policy,

$y_{i}=1$ if the farmer has a partial-type (single risk) insurance policy,

$y_{i}=2$ if the farmer has a full-type (combined) insurance policy,

$x_{i} \quad$ the vector of the exogenous variables,

$b$ the coefficients' vector,

$c_{j}, j=\overline{0,3}$ cutoffs, 


\section{Finance}

$c_{0}=-\infty, \quad c_{j} \leq c_{j+1}, \quad c_{3}=+\infty$ conditions that ensure that the probability sum for each interval equals 1 .

b) The Binary Logit model was used to explain the decision to buy an insurance policy:

$$
\left\{\begin{array}{l}
\operatorname{Prob}\left(y_{i}=1\right)=F\left(x_{i} b\right)=\frac{\exp \left(x_{i} b\right)}{1+\exp \left(x_{i} b\right)} \\
\operatorname{Prob}\left(y_{i}=0\right)=1-F\left(x_{i} b\right)=\frac{1}{1+\exp \left(x_{i} b\right)}
\end{array}\right.
$$

$i=\overline{1, N}$ index of each farmer,

$y_{i}=1$ if the farmer has an insurance policy (partial or full type),

$y_{i}=0$ if not,

$x_{i} \quad$ the vector of the exogenous variables,

$b \quad$ the coefficients' vector.

Tab. 2: Estimation of Ordered Logit model and Binary Logit model

\begin{tabular}{|c|c|c|c|c|}
\hline & \multicolumn{2}{|c|}{ Ordered Logit model } & \multicolumn{2}{|c|}{ Binary Logit model } \\
\hline & coefficient & std. err. & coefficient & $\begin{array}{c}\text { marginal eff. } \\
\mathrm{dy} / \mathrm{dx}\end{array}$ \\
\hline Radical inhabitants & ${ }^{* *} 0.0281$ & 0.0119 & ** 0.0301 & 0.0041 \\
\hline Distance city & ${ }^{\star *}-0.0314$ & 0.0126 & ${ }^{* * *}-0.0345$ & -0.0047 \\
\hline Age & ${ }^{\star \star}-0.0280$ & 0.0129 & ${ }^{* *}-0.0278$ & -0.0038 \\
\hline Education & ${ }^{\star \star} 0.5937$ & 0.2813 & ${ }^{\star *} 0.6032$ & 0.0828 \\
\hline Cultivated area & * 0.1382 & 0.0809 & 0.1357 & 0.0186 \\
\hline Agricultural studies & 0.3291 & 0.4608 & 0.4486 & \# 0.0686 \\
\hline Economic studies & ${ }^{\star *} 0.7628$ & 0.3781 & ${ }^{\star *} 0.8526$ & \# 0.1364 \\
\hline Vegetables (dummy) & ${ }^{* * *} 1.2880$ & 0.4801 & ${ }^{\star * *} 1.3404$ & \# 0.2304 \\
\hline Vine (dummy) & 0.0583 & 0.5661 & 0.1136 & \# 0.0159 \\
\hline Field crops (dummy) & 0.4569 & 0.4628 & 0.5303 & \# 0.0756 \\
\hline Pomiculture (dummy - reference) & 0.0000 & - & 0.0000 & - \\
\hline \multirow[t]{2}{*}{ Constant } & - & - & ** -2.1125 & - \\
\hline & \multicolumn{2}{|c|}{$\begin{aligned} \text { Log likelihood } & =-134.00673 \\
\text { LR chi2 } 2(10) & =49.43 \\
\text { Prob }>\text { chi2 } & =0.0000 \\
\text { Pseudo R2 } & =0.1557\end{aligned}$} & \multicolumn{2}{|c|}{$\begin{aligned} \text { Log likelihood } & =-178.57244 \\
\text { LR chi2 }(10) & =49.16 \\
\text { Prob }>\text { chi2 } & =0.0000 \\
\text { Pseudo R2 } & =0.1210\end{aligned}$} \\
\hline
\end{tabular}

\# dy/dx is for discrete change of dummy variable from 0 to 1 
The majority of the results are as expected (Tab. 2). For the number of inhabitants, we opted for a transformation of the initial variable. The positive sign of the coefficient is to be explained by the fact that, in general, smaller communities are more traditionalist, people preferring the ancestral behaviour of helping one another in the case of natural disasters. The same traditionalism causes the sign of the Distance city and Age variables. On the other hand, the size of the cultivated area, even though having the expected sign, is not very significant.

The level of education is a determinant factor, this being a problem in the Romanian villages. The majority of the persons that choose to attend university courses usually remain in towns. The weight of university graduates in the active population in 2009 was of only $4.0 \%$ in the rural area (in comparison with $25.4 \%$ in the urban area). At the opposite pole, the percentage of the inhabitants having a primary or secondary school diploma in rural areas was $39.5 \%$, while in the urban areas it was only $8 \%$. This is probably the most important factor that determines the functioning of the crop insurance market much below its potential. In what regards the type of courses attended, surprisingly, the ones related to agriculture do not significantly influence the decision of insurance. On the other hand, studies that involve the economic aspect are decisive as they familiarize the subject with the mechanisms and the regulations related to the insurance market.

Very interesting are the results related to the main crop type. Farmers that grow vegetables are much more interested in insuring the crops than the others (regardless of the dummy variable taken as reference). Among the other types of cultures analyzed there are no statistically significant differences, regardless of the dummy variable considered as reference. In the case of vegetables, investments in greenhouses and solaria are necessary in order to extend their cultivation in the cold season. Some natural calamities can lead to the destruction of these investments together with the culture. This brings along a significantly higher risk and, in consequence, the increase of the probability to opt for a suitable insurance product.

\section{Conclusions}

The goal of the present research was to find possible factors that affect the decision of buying an agricultural insurance policy in Romania. As it could be seen in the first parts of the paper, the development of this risk management tool in agriculture is low in Romania. The literature reviewed suggests that this level is the same in other developing countries. Consequently, the results of the present research could be used not only in the case of Romania, for decisions regarding the development of the agricultural insurance sector, but also in other countries with similar features. Moreover, the presented methodology can be applied, as long as data exists, on different samples to extract their specificities.

The results of the regression models have shown that age is an important factor - the older the farmer, the lower the probability to make an insurance policy in agriculture. This is somehow expected for countries like Romania. The persons employed in agriculture are, in general, old. They work in this field either because they are retired and they do it as a hobby, or because this is the only way in which they can provide incomes for their families. Such persons are more traditionalist and more averse to new information, to things they are not used to. They lack the openness towards lifelong learning. Such a result shows the need for educational programmes supported by authorities or private entities to inform about the benefits of modern risk management procedures in agriculture that could help increase the utility of the activity.

At present, in Romania, the traditional agricultural insurance programmes are prevalent. These have proved to be inefficient for small farmers because of the high administrative costs (a very significant variable in our study was the vicinity to an important town). The proximity to a town is strongly correlated with the closeness to an insurance company agency. The more isolated the village, the higher the administrative expenses. In order to reduce these expenses, some alternative insurance programmes like Index Based Agricultural Insurance appeared and it would be interesting to develop them in the future. Additionally, the longer the distance from the farm to the nearest important city, again, the 
lower the probability of agricultural risk management through such tools. Beside the costs issue, this result also emphasizes the fact that information is usually disseminated in large cities and emphasises the difficulties of being informed for persons that live far away from the urban areas.

Another highly relevant variable in our estimation is the number of inhabitants of the village. In small villages, generally more traditional, institutionalized insurance is avoided, mutual aid in the case of calamities being preferred by producers. In such cases, a more adequate approach, much more appropriate to the natural behaviour of these farmers, is an Area Insurance Plan, which means that farmers are insured as a group.

The study also shows that educated people are more open towards insurance tools. What is interesting is that a background in agriculture studies, although expected to be a major factor of influence, has very little impact upon the decision. Economic studies are found to have much more influence because they better emphasize the advantages of using insurance as a protection tool against risks in any field, including agriculture.

Our study also provides information about how the type of crop affects the subscription of an insurance policy. It seems that in Romania only farmers that grow vegetables have understood the importance of protection against natural disasters. However, farmers must be made aware of the fact that protection is needed for all types of crops, because of the low probability of forecasting the risks associated with natural phenomena. A rainy year can cause, for example, important losses for farmers working in the vinery field. The State should sustain promotion and information measures for crop insurance systems.

The improper development of the agricultural insurance sector goes hand in hand with a propensity for risk retention for the farmers. Such studies that identify the factors affecting crop insurance can be used by insurance companies for outlining a consumer profile, for this insurance line of business, more adapted to consumer needs. The study can also be used by decisional entities in order to better assess issues and policies related to the sector. The approach should assist the development of the kind of policies that may increase the efficiency of the economic mechanisms in agriculture, especially through information and education. However, the poor development of the market due to some factors such as the education level, the type of studies and age can hardly be compensated for by innovative policies. These features can be solved only over time by an adequate socio-economic evolution, including education.

\section{References}

[1] ALMAJANU, F. Crop Insurance Market - between Potential and Reality. In Proceedings of Conference: The Development of the Romanian Agriculture. Bucharest, Romania: Romanian Banking Institute, 2011.

[2] BECIU, S., POPA, O., NISTOR, S. and OLTEANU, V. The socio-economic dimension of rural development for the North-East Region of Romania. African Journal of Agricultural Research. 2011, Vol. 6, Iss. 28, pp. 6042-6051. ISSN 1991-637X.

[3] BIELZA, M., CONTE, C., DITTMANN, CH., GALLEGO, J. and STROBLMAIR, J. Agricultural Insurance Schemes. Final Report. European Commission. Institute for the Protection and Security of the Citizen. Agriculture and Fishing. 2008. Unit: 517-569.

[4] BINSWANGER-MKHIZE, H.P. Is There Too Much Hype about Index-based Agricultural Insurance? Journal of Development Studies. 2012, Vol. 48, Iss. 2, pp. 187-200. ISSN 0022-0388.

[5] BOYD, M., PAI, J., QIAO, Z. and KE, W. Crop Insurance Principles and Risk Implications for China. Human and Ecological Risk Assessement: An International Journal. 2011, Vol. 17, Iss. 3, pp. 554-565. ISSN 1080-7039.

[6] BUENO-AGUILAR, G., ARJONA-SUAREZ, E. and SANTIAGO-ZARAGOZA, L. A simulation model for the analysis of new operating policies in a corn flour production plant. Agrociencia-Mexico. 2011, Vol. 45, Iss. 2, pp. 207-220. ISSN 1405-3195.

[7] CLIPICl, E. and FRANT, F. The Evolution of Agricultural Insurance Market. Agricultural Management. Banat's University of Agricultural Science and Veterinary Medicine from Timisoara. 2013, Vol. 15, Iss. 3, pp. 1-8. ISSN 1453-1410.

[8] CRISTEA, M., DRACEA, R. and BUZIERNESCU, R. Possible Risk Coverage in Agriculture through Agricultural Insurances. Bulletin of University of Agricultural Sciences and Veterinaty Medicine Cluj-Napoca. Horticulture. 2006, Vol. 63, Iss. 1-2, pp. 157-162. ISSN 1843-5254. 
[9] DICK, W.J.A. and WANG, W. Government Interventions in Agricultural Insurance. Agriculture and Agricultural Science Procedia. 2010, Vol. 1, pp. 4-12. ISSN 2210-7843.

[10] DINCĂ, D. Rural Administration in Romania: Evaluation of Current State. Transylvanian Review of Administrative Sciences. 2012, No. 36E, pp. 71-91. ISSN 1842-2845.

[11] DINU, V., SCHILERU, I. and ATANASE, A. Attitude of Romanian Consumers Related to Products' Ecological Labelling. Amfiteatru Economic. 2012, Vol. 14, Iss. 31, pp. 8-24. ISSN 1582-9146. [12] DRAGOS, C., VERES, V. Romanian Farmer's Market. A Multinomial Logit Model Approach. Proceedings of Rijeka Faculty of Economics, Journal of Economics and Business. 2007, Vol. 25, Iss. 2, pp. 291-308. ISSN 1331-8004.

[13] ENJOLRAS, G. and SENTIS, P. Crop insurance policies and purchases in France. Agricultural Economics. 2011, Vol. 42, Iss. 4, pp. 475-486. ISSN 1574-0862.

[14] FURDU, I., TOMOZEI, C. and PANDELE, I. Improving Management of Risks and Natural Disasters by Regional GIS Distributed Application. Environmental Engineering and Management Journal. 2013, Vol. 12, Iss. 1, pp. 11-16. ISSN 1582-9596.

[15] GARDNER, B.L. and KRAMER, R.A. Experience with Crop Insurance Programs in the United States. In HAYELL, P., POMAREDA, C., VALDES, A. (Eds.). Crop Insurance for Agricultural Development. Baltimore: Johns Hopkins University Press, Maryland. 1986. pp. 195-222.

[16] GIRDZIUTE, L. and SLAVICKIENE, A. Decision making in agriculture and insurance as a risk management tool. Zemes Ukio Mokslai. 2012, Vol. 19, Iss. 1, pp. 45-52. ISSN 1392-0200.

[17] GOMEZ-LIMON, J., ARRIAZA, M. and RIESGO, L. An MCDM analysis of agricultural risk aversion. European Journal of Operational Research. 2003, Vol. 151, Iss. 3, pp. 569-585. ISSN 0377-2217.

[18] HARDAKER, J.B., RICHARDSON, J.W., LIEN, G. and SCHUMANN, K.D. Stochastic efficiency analysis with risk aversion bounds: a simplified approach. Australian Journal of Agricultural in Resource Economics. 2004, Vol. 48, Iss. 2, pp. 253-270. ISSN 1467-8489.

[19] MAKKI, S.S. Crop Insurance: Inherent Problems and Innovative Solutions. In TWEETEN, L. and THOMPSON, S.R. (Eds.). Agricultural Policy for the 21st Century. Ames, lowa: lowa State Press, 2008. ISBN 978-0813808994.
[20] MAKRIDAKIS, S., WHEELWRIGHT, S.C. and HYNDMAN, R.J. Forecasting - methods and application. 3rd ed. Chichester: John Wiley \& Sons Inc, 1998. 656 p. ISBN 978-0471532330.

[21] MARE, C. Scenarios and Prospective Regarding the Euro Introduction on the Romanian Market. Gorizia, 2010. 250 p. Disertation Thesis (PhD.). International University Institute for European Studies. Available also from: http://hdl.handle.net/ 10077/3485.

[22] MITU, E.N. Agricultural Insurances in Romania: Present and Future Aspects [online]. Munich Personal RePEc Archive, 2007. Paper no. 10773. [cit 2013-11-10]. Available from: http://mpra.ub. uni-muenchen.de/10773/.

[23] NIEUWOUDT, W.L. An economic evaluation of a crop insurance programme for small-scale commercial farmers in South Africa. Agrekon. 2000, Vol. 39, Iss. 3, pp. 269-291. ISSN 0303-1853.

[24] NJEGOMIR, V. and STOJIC, D. Determinants of Non-Life Insurance Market Attractiveness for Foreign Investments: Eastern European Evidence. Economic Research - Ekonomska istraživanja. 2012, Vol. 25, Iss. 2, pp. 297-310. ISSN 1331-677X.

[25] RAHMAN, M.W., LUO, J. and CHENG, E. Policies and performances of agricultural/rural credit in Bangladesh: what is the influence on agricultural production? African Journal of Agricultural Research. 2011, Vol. 6, Iss. 31, pp. 6440-6452. ISSN 1991-637X.

[26] RAMIREZ-VALVERDE, G., ISLAS-MONROY, J.C. and RAMIREZ-VALVERDE, B. Spurious association in logistic time series binary regression models. Agrociencia-Mexico. 2011, Vol. 45, Iss. 5, pp. 583-591. ISSN 1405-3195.

[27] SAHAT, M. and PASARIBU, S.M. Developing rice farm insurance in Indonesia. Agriculture and Agricultural Science Procedia. 2010, Vol. 1, pp. 33-41. ISSN 2210-7843.

[28] SAI, T., YULIAN, W. and XIAOFENG, H. An empirical study of agricultural insurance - evidence from China. Agriculture and Agricultural Science Procedia. 2010, Vol. 1, pp. 62-66. ISSN 2210-7843. [29] SAIKIA, D. Analyzing inter-sectoral linkages in India. African Journal of Agricultural Research. 2011, Vol. 6, Iss. 33, pp. 6766-6775. ISSN 1991-637X.

[30] SIFUENTES-AMAYA, R. and RAMIREZ-VALVERDE, G. Effects of specifying an incorrect model for logistic regression, with two independent correlated variables. Agrociencia-Mexico. 2010, Vol. 44, Iss. 2, pp. 197-207. ISSN 1405-3195. 


\section{Finance}

[31] ŞTEFĂNESCU, F. A. D. Xenopol on the Means of Improving Agriculture and the Romanian Villages. Transylvanian Review. 2010, Vol. 3, pp. 50-61. ISSN 1221-1249.

[32] TOLEDO, R. and ENGLER, A. Risk preferences estimation for small raspberry producers in the Bio-Bio Region, Chile. Chilean Journal of Agricultural Research. 2008, Vol. 68, Iss. 2, pp. 175-182. ISSN 0365-2807.

[33] TURVEY, C.G. An Economic Analysis of Alternative Farm Revenue Insurance Policies. Canadian Journal of Agricultural Economics/Revue canadienne d'agroeconomie. 1992, Vol. 40, Iss. 3 , pp. 403-426. ISSN 1744-7976.

[34] VARGAS-LEITON, B. and CUEVASABREGO, M. Stochastic model to estimate economic values of production and functional traits in diary cattle. Agrociencia-Mexico. 2009, Vol. 43, Iss. 8, pp. 881-893. ISSN 1405-3195.

[35] VASILE, E., BALAN, M., MITAN, D. and CROITORU, I. The restructuring of Romanian agriculture. Romanian Agricultural Research. 2011, Vol. 28, pp. 263-270. ISSN 1222-4227.

[36] VIDICAN, G. Assessing land reallocation decisions during transition in Romania. Land Use Policy. 2009, Vol. 26, pp. 1080-1089. ISSN 0264-8377.
[37] XU, P., KONG, X., ZHONG, Z. and WILLIAMS, L. Agricultural assistance in China: An analysis of farmers' opinions. African Journal of Agricultural Research. 2011, Vol. 6, Iss. 30, pp. 6377-6386. ISSN 1991-637X.

Lect. univ. dr. Simona Laura Dragos Babes-Bolyai University of Cluj Napoca, Romania

Faculty of Economics and Business Administration Department of Finance simona.dragos@econ.ubbcluj.ro

Lect. univ. dr. Codruta Mare Babes-Bolyai University of Cluj Napoca, Romania

Faculty of Economics and Business Administration Department of Statistics-ForecastingMathematics codruta.mare@econ.ubbcluj.ro 


\title{
Abstract
}

\section{AN ECONOMETRIC APPROACH TO FACTORS AFFECTING CROP INSURANCE IN ROMANIA}

\author{
Simona Laura Dragos, Codruta Mare
}

Crop insurance is a very well implemented mechanism in the economic and agricultural sectors of the developed countries. In the developing countries there are yet in practice traditional local systems of helping the other in the case of natural disasters. The transition to an organized system, based on buying insurance policies, is a very slow process and is, for the moment, used and accepted only by big land owners. The study based on a sample of 308 small farmers in Romania analyzes the factors influencing the decision of buying an insurance policy: age, education, size of the village, the proximity to a city, the type of culture, etc. The sampling method aimed at ensuring representativity on several levels: regional - villages from different counties; education - different levels of education for farmers and different fields of study; type of village - villages of different sizes and situated at various distances from towns; type of crop - farmers that mainly deal with vegetables, pomiculture, vine and field crops. Through two econometric models, Ordered Logit and Binary Logit, both the decision of buying an insurance policy and the type of insurance chosen (partial or full) are assessed. Results show a higher propensity towards using the insurance system in the case of younger farmers who have had access to tertiary education (especially in the field of economics and business), who live in big villages near important cities and who cultivate vegetables. Even though the study is regional, the emphasized mechanisms are universally valid and can be used by policymakers from developing economies.

Key Words: Crop insurance, ordered logit, binary logit, Romania.

JEL Classification: C25, Q12, G22.

DOI: 10.15240/tul/001/2014-1-008 